\title{
1 Effect of oxygen transfer on yeast growth - growth kinetic 2 and reactor model to estimate scale-up effects in 3 bioreactors
}

4 Petri Tervasmäki*1, Marko Latva-Kokko², Sanna Taskila ${ }^{1}$, Juha Tanskanen ${ }^{1}$

5 ' ${ }^{1}$ University of Oulu, Chemical Process Engineering, P.O. Box 4300, Fl-90014 Oulun yliopisto, Finland

6 2Outotec Oyj, Outotec Research Center, P.O. Box 69, FI-23101 Pori, Finland

7 *Corresponding author, petri.tervasmaki@oulu.fi, +358 405474973

8 Abstract

9 Large scale fermentations face challenges in mixing and mass transfer as well as in the design and 10 construction of the equipment. Scale-up from laboratory and pilot scale experiments is difficult 11 because different phenomena - such as mixing times and mass transfer conditions - scale in a 12 different way.

13 We study the effect of mass transfer, reactor type and scale on the growth of Pichia pastoris yeast.

14 Batch cultivation experiments monitoring the cell growth and ethanol formation are conducted in 15 laboratory scale in two reactor types - stirred tank and an Outotec OKTOP®9000 draft tube reactor. 16 Model for the yeast growth - including respirative and fermentative metabolism and the effect of 17 dissolved oxygen - is formed based on literature. For scale-up studies, the growth model is used 18 along with one dimensional reactor model that accounts for liquid mixing, gas phase dynamics and 19 local gas hold-up and mass transfer coefficient.

20 By using a realistic growth model along with the reactor model, the simulated effects of scale-up 21 are presented in terms of cell yield. A decrease in yield is noticed due to oxygen depletion in gas and 22 insufficient liquid mixing. Potential improvements are related to the gas handling capacity and liquid 23 mixing of the reactor.

24 Keywords

25 Scale-up; Mass transfer; Bioreactor; Stirred tank; Draft tube; Model 


\section{Nomenclature}

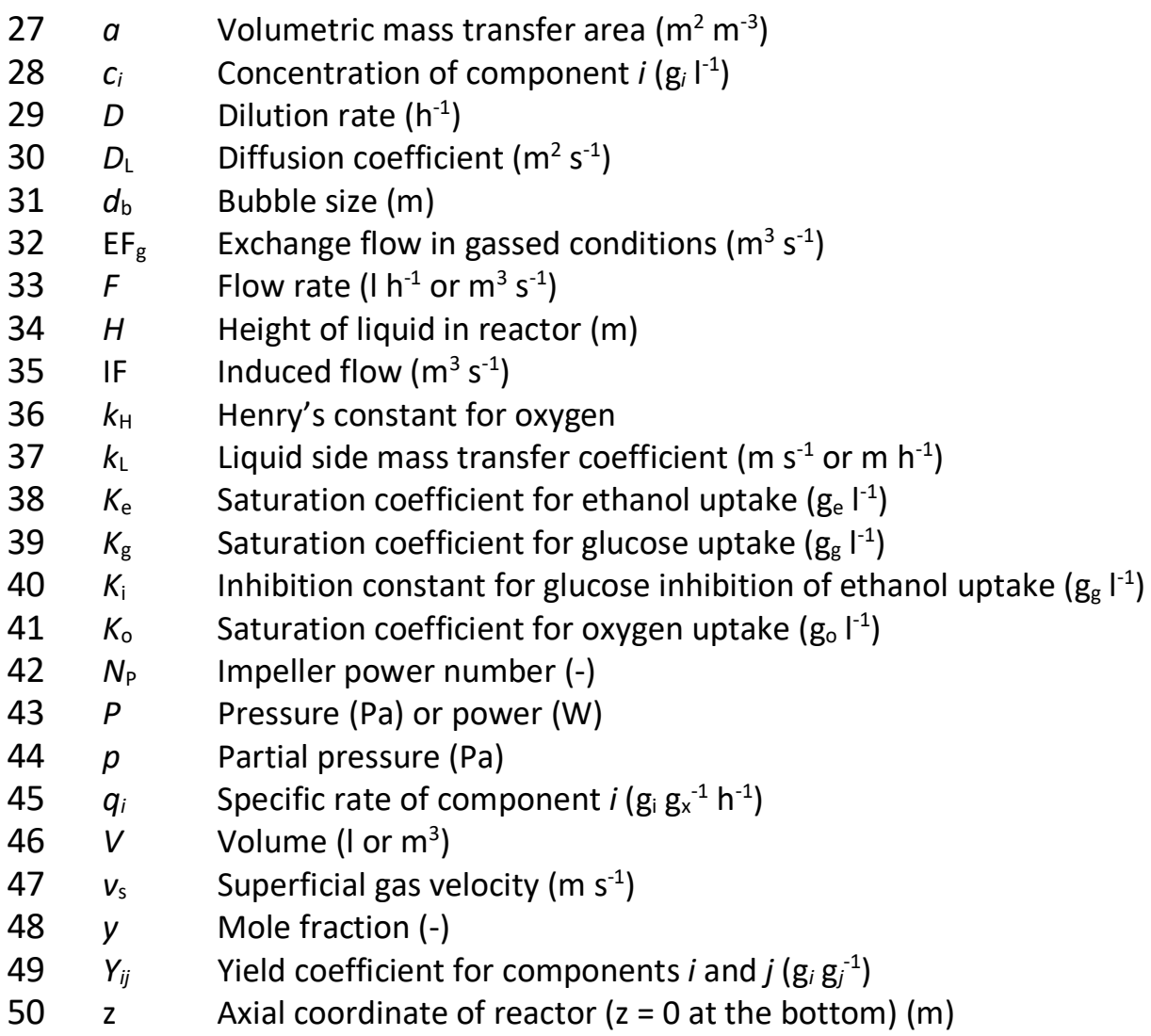

\section{Greek letters}

$52 \eta \quad$ Viscosity (Pa s)

$53 \mu \quad$ Growth rate $\left(\mathrm{h}^{-1}\right)$

$54 \rho \quad$ Density $\left(\mathrm{kg} \mathrm{m}^{-3}\right)$

$55 \tau \quad$ Gas phase residence time (s or $\mathrm{h}$ )

$56 \phi \quad$ Gas volume fraction (-)

\section{Subscripts and superscripts}

$\begin{array}{lll}58 & \text { e } & \text { ethanol } \\ 59 & \text { ferm } & \text { fermentative pathway } \\ 60 & \mathrm{~g} & \text { glucose } \\ 61 & \text { gas } & \text { gas phase } \\ 62 & \text { o } & \text { oxygen } \\ 63 & \text { ox } & \text { oxidative pathway } \\ 64 & \text { sat } & \text { saturation concentration } \\ 65 & x & \text { cells }\end{array}$


67 The majority of industrial microbial processes are aerobic, meaning that the cells consume oxygen

68 for cellular respiration. Due to the low solubility of oxygen in aqueous solutions, oxygen needs to be

69 continuously dissolved from gas to the liquid phase by introducing air or another gas containing oxygen into the reactor. Ideally, the oxygen transfer rate of the reactor is sufficient to maintain the dissolved oxygen concentration above a critical value, thus matching the oxygen uptake rate of the cells. There are complex interactions between the hydrodynamics of the reactor, mass transfer parameters, and microbial growth. (Garcia-Ochoa et al., 2010; Garcia-Ochoa and Gomez, 2009)

Simple scale-up rules and related correlations are frequently discussed in the literature. One popular approach is correlations based on the mixing power per liquid volume to maintain similar values for overall volumetric mass transfer coefficient, $k\llcorner a$. As pointed out by Nauha et al., (2015); the exponents in the common correlations are scale-dependent which limits their applicability in scaling up industrial processes. They also pointed out issues related to hydrodynamic regimes and oxygen mass balance in industrial scale aerobic fermentations.

Gas sparged below the impeller of a stirred tank reactor forms cavities behind the low pressure areas of the impeller blades. Depending on the impeller geometry and rotation rate as well as the gas flow rate, gas is dispersed by the impeller with varying efficiency. Flow regimes at the impeller can be roughly categorized, with increasing dispersion efficiency, to flooding, loading and complete recirculation. (Paul et al., 2004) However, even with sufficient gas dispersion by the impeller, high gas flow rates may cause a transition from homogeneous to heterogeneous flow regime, which is characterized by formation of large bubbles and bimodal bubble distribution. The flow in

87 heterogeneous regime is more controlled by the gas flow rate. The transition depends mainly on the superficial gas velocity and occurs approximately at $v_{\mathrm{s}}=0.03 \mathrm{~m} / \mathrm{s}$. (Gezork et al., 2000)

The superficial gas velocity is also present in many correlations, and it is often used to estimate the gas flow rate in different scales. If the gas flow is scaled by constant $v_{s}$, volumetric gas flow related

91 to liquid volume, expressed as volume gas per volume liquid per minute (VVM), decreases as it scales by $V^{-1 / 3}$. When considering the stoichiometry in the process, maintaining constant VVM would be 
advantageous. However, the maximum value for $v_{s}$ to maintain a homogeneous flow regime that is controlled by the agitator is considered to be about $0.03 \mathrm{~m} \mathrm{~s}^{-1}$. Therefore, due to a decreased VVMvalue in large reactors, gas phase residence time increases with scale, and gas phase depletion is more significant. This decreases the driving force for mass transfer, which may lead to mass transfer limited conditions.

The effect of hydrostatic pressure on the flow regime is also notable in large vessels with high aspect ratios. At higher pressure, the conditions controlling homogeneous/heterogeneous transition conditions are different, due to increased gas density. Therefore, it may be that flow in the bottom part is homogeneous and transition to heterogeneous flow regime occurs in the higher parts of the reactor. The effect may be similar for the flooding/loading transition of the impellers. (Nauha et al., 2015) The flooding regime of the impellers, however, needs to be distinguished from the homogeneous/heterogeneous flow regime, and it is affected by gas flow rate and the diameter, revolution rate and geometry of the impeller.

The applicability of stirred draft tube reactors (SDTR) on microbial fermentations has been shown in previous studies (Moo-Young et al., 1993; Pollard et al., 1997). In addition, different SDTR designs have been compared to airlift (ALR, Chisti and Jauregui-Haza, 2002) and stirred tank reactors (STR, Lueske et al., 2015) in mixing and mass transfer studies. The SDTR was found to have higher efficiency for mass transfer compared to STR but not to ALR. Recently, a scaled down model of industrial scale bottom-agitated draft tube reactor (Outotec OKTOP®9000) was shown to perform well in mixing and mass transfer experiments and was also suitable for cell cultivations (Tervasmäki et al., 2016). This reactor type has been used in the hydrometallurgical industry for direct leaching of zinc concentrate in scales up to $1000 \mathrm{~m}^{3}$, which is a rather large scale for multiphase stirred tank reactor.

In this study, we further investigate the performance of different reactor types in lab-scale yeast cultivations using Pichia pastoris yeast. It does not exhibit glucose repression of respiration and, therefore, is suitable for batch cultivation. Furthermore, its fermentative metabolism that produces mainly ethanol is activated at oxygen limitation (Baumann et al., 2008; Carnicer et al., 2009). Therefore, the presence of ethanol can be used as an indication of oxygen limitation even if 
121 dissolved oxygen cannot be measured or if there are significant gradients, which may be the case 122 especially in larger reactors. A kinetic model for the growth of $P$. pastoris on glucose, including the 123 fermentative route in oxygen limited conditions and ethanol utilization, is formed based on 124 chemostat cultivations presented in the literature. The model is qualitatively compared with batch 125 cultivations in a laboratory-scale reactor. It is also applied in simulations along with a simple one126 dimensional reactor scale model to assess the importance of scale-up effects - such as gas phase 127 oxygen depletion, hydrostatic pressure, and liquid mixing - on oxygen transfer and cell yield during 128 scale-up. The model is designed to be computationally light so that it can be applied also in the 129 simulation of CFD-models developed for different reactors including the STDR, for example.

\section{Materials and methods}

131 Laboratory scale batch cultivations were carried out using Pichia pastoris X33 yeast in batch 132 cultivations with two reactor types: OKTOP $9000^{\circledR}$ and stirred tank reactor agitated with three 133 Rushton turbines. The main geometrical parameters are presented in Figure 1, and more 134 information of the reactors including gas dispersion and mass transfer performance can be found 135 from Tervasmäki et al. (2016). For the cultivation experiments, inoculum was cultivated overnight 136 in a liquid YPD-medium in baffled shake flasks $(2 \times 500 \mathrm{ml})$, and the bioreactor cultivations (Biostat

137 C-DCU, Sartorius, Germany) were carried out in a basal salt medium supplied with $4.35 \mathrm{ml} / \mathrm{I}$ PTM 1 138 trace salts at a temperature of $30{ }^{\circ} \mathrm{C}$ (Table 1 ). The liquid volumes were 10 I (STR) and 12.5 । 139 (OKTOP $\left.{ }^{\circledR}\right)$, and the reactor diameter was $190 \mathrm{~mm}$. Gas flow was set to $18 \mathrm{l} / \mathrm{min}\left(v_{\mathrm{s}}=0.011 \mathrm{~m} / \mathrm{s}\right.$ or $1401.5-1.8 \mathrm{VVM}$ ), and the agitation rate was $450 \mathrm{rpm}$ and $720 \mathrm{rpm}$ for STR and OKTOP ${ }^{\oplus}$, respectively. 141 This corresponds to volumetric power consumption of about $500 \mathrm{~W} / \mathrm{m}^{3}$. Aqueous ammonium 142 hydroxide (25\%) was used to adjust the pH between 5 - 5.5; an antifoam agent (Antifoam 204, 143 Sigma-Aldrich) was used to control the foam. Dissolved oxygen was measured from the lower 144 (approx. $10 \mathrm{~cm}$ from bottom, Oxyferm FDA 120, Hamilton, Switzerland) and upper part of the 145 reactor (approx. $10 \mathrm{~cm}$ from surface, Visiferm, Hamilton, Switzerland). Concentrations of oxygen, 146 carbon dioxide and hydrocarbons were measured by Innova 1313 gas analyser (LumaSense, 147 Denmark). 
Manual samples were collected during fermentation to measure cell dry weight (CDW) and glucose, ethanol, acetate and glycerol concentrations. Cell dry weight was measured by transferring $2 \mathrm{ml}$ of sample suspension into pre-weighed centrifuge tubes (triplicates), which were centrifuged, after

151 which the remaining cell pellet was suspended in $0.9 \% \mathrm{NaCl}$, centrifuged again and dried for 24

152 hours at $60^{\circ} \mathrm{C}$ before weighing. The standard deviation of the cell dry weight measurements were 153 in general well below $5 \%$ of the measured value except for the initial measurements with very low 154 cell concentrations. Glucose, ethanol, acetate and glycerol were measured by HPLC (Agilent 1200 155 series) equipped with ICSep ICE-Coregel $87 \mathrm{H}$-column. $5 \mathrm{mM} \mathrm{H}_{2} \mathrm{SO}_{4}$ was used as a mobile phase with 156 a flow rate of $0.6 \mathrm{ml} / \mathrm{min}$ and column temperature was controlled at $60^{\circ} \mathrm{C}$. The compounds were 157 detected with a refractive index detector (RID). The gas analyser reacts to ethanol in off-gas, and a 158 correlation was established between the raw data from the gas analyser and the measured ethanol 159 concentration of the samples. Thus, the data from the gas analyser could be used as an online 160 measurement for ethanol. The estimation of liquid phase ethanol concentration from the off-gas 161 depends on evaporation of ethanol from liquid to the gas phase. The agitation and aeration were 162 maintained constant in the above experiments so similar conditions for reaching the vapour-liquid 163 equilibrium during the cultivation could be assumed, and a good correlation $\left(R^{2}=0.99\right)$ was 164 established between the ethanol concentration measured from liquid samples (HPLC) and off-gas 165 signal. There was still some deviation, and an error margin of about $10 \%$ can be considered for the 166 ethanol estimation from off-gas. At very low ethanol concentrations below $1 \mathrm{~g} / \mathrm{l}$, the error may be 167 even more than $50 \%$ but accurate on-line monitoring of very low ethanol concentrations is not 168 critical for the experiments in this study. 
170 Table 1. Basal salt medium (BSM) and PTM $_{1}$ trace salts used in the reactor cultivations.

\begin{tabular}{|c|c|c|c|c|c|}
\hline Basal Salt Medium & & & PTM $_{1}$ Trace Salts & & \\
\hline $\begin{array}{l}\text { Phosphoric acid (85 } \\
\%)\end{array}$ & 24.0 & $\mathrm{ml} / \mathrm{l}$ & $\begin{array}{l}\text { Copper sulfate } \\
\text { (pentahydrate) }\end{array}$ & 6 & $g / l$ \\
\hline Calcium sulfate & 0.93 & $g / l$ & $\begin{array}{l}\text { Sodium iodide } \\
\text { Manganese }\end{array}$ & 0.08 & $g / l$ \\
\hline Potassium sulfate & 18.2 & $g / l$ & $\begin{array}{l}\text { sulfate } \\
\text { (monohydrate) }\end{array}$ & 3 & $g / l$ \\
\hline $\begin{array}{l}\text { Magnesium sulfate } \\
\text { (heptahydrate) }\end{array}$ & 14.9 & $\mathrm{~g} / \mathrm{l}$ & $\begin{array}{l}\text { Sodium } \\
\text { molybdate } \\
\text { (dihydrate) }\end{array}$ & 0.2 & $\mathrm{~g} / \mathrm{l}$ \\
\hline $\begin{array}{l}\text { Potassium } \\
\text { hydroxide }\end{array}$ & 4.13 & $\mathrm{~g} / \mathrm{l}$ & Boric acid & 0.02 & $\mathrm{~g} / \mathrm{l}$ \\
\hline \multirow[t]{5}{*}{ Glucose } & 80 & $g / l$ & Cobalt chloride & 0.5 & $g / l$ \\
\hline & & & Zinc chloride & 20 & $\mathrm{~g} / \mathrm{l}$ \\
\hline & & & $\begin{array}{l}\text { Ferrous sulfate } \\
\text { (heptahydrate) }\end{array}$ & 65 & $\mathrm{~g} / \mathrm{l}$ \\
\hline & & & Biotin & 0.2 & $\mathrm{~g} / \mathrm{l}$ \\
\hline & & & Sulfuric acid & 5 & $\mathrm{ml} / \mathrm{l}$ \\
\hline
\end{tabular}

171 

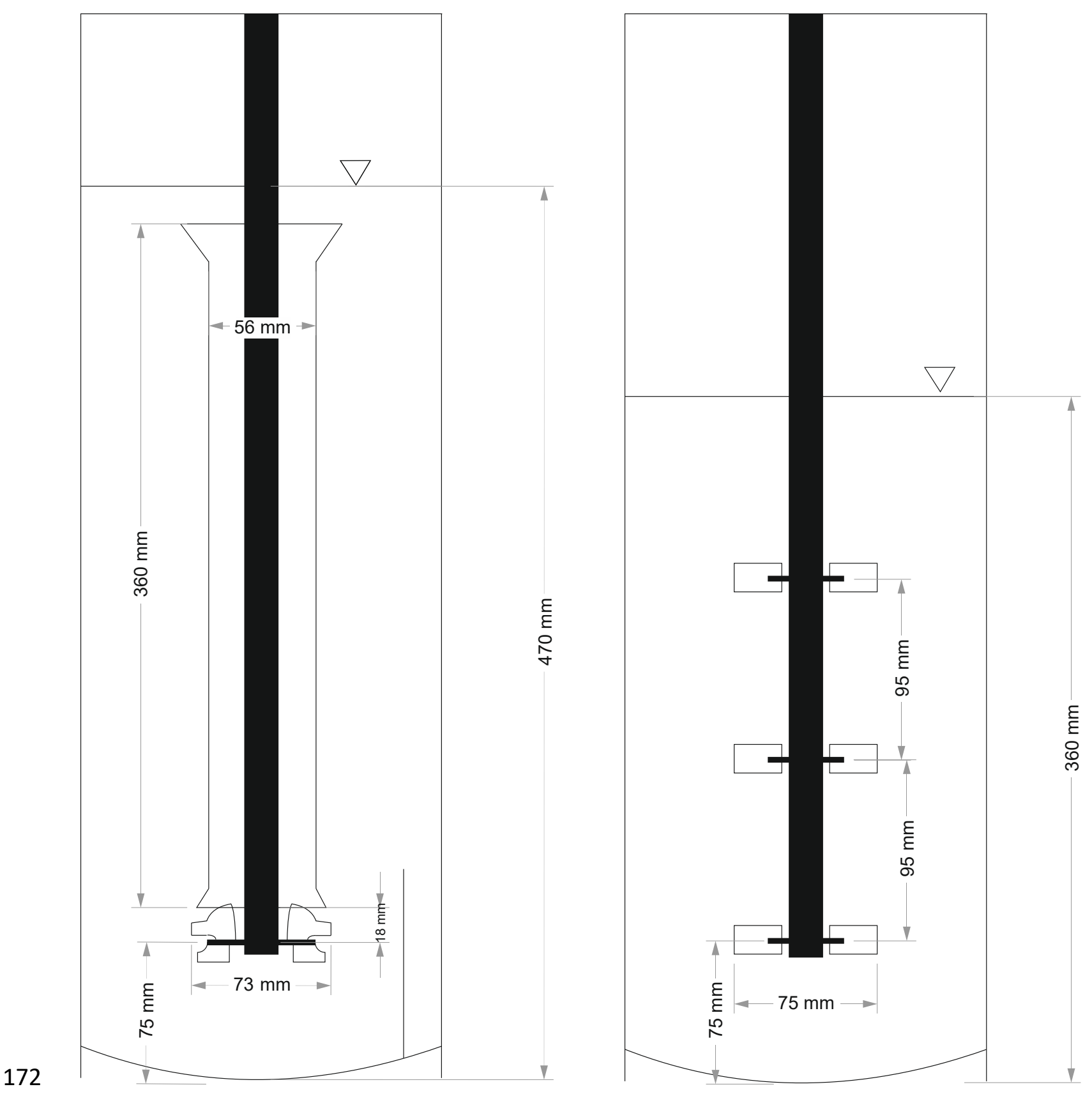

173 Figure 1. Reactor geometries for laboratory scale cultivations, OKTOP®9000 (left) and Rushton (right).

\section{Modelling approach}

\subsection{Growth model for Pichia pastoris}

176 The model is modified from the one presented by Sonnleitner and Käppeli (1986) for Saccharomyces

177 cerevisiae. In the original model, specific glucose uptake is modelled using Monod kinetics with a 
low value for saturation coefficient. If the glucose uptake rate exceeds the oxidative capacity of the cell, the rest of the glucose flux is directed towards fermentative metabolism producing ethanol thus capturing the glucose effect present in S. cerevisiae but not in P. pastoris. Therefore, the current model is modified so that the specific glucose uptake rate $\left(q_{\mathrm{g}}\right)$ is dependent on the growth rate and it is assumed that the oxidative capacity of the cells exceeds the oxygen requirement even at the maximum growth rate, given that oxygen transfer rate of the reactor is sufficient to maintain dissolved oxygen above a critical level. In addition, ethanol can also be utilized as a carbon source if oxygen is available and glucose is not present in the medium. The net stoichiometric equations of the three metabolic routes are as follows:

$\mathrm{C}_{6} \mathrm{H}_{12} \mathrm{O}_{6}+a \mathrm{O}_{2}+b N X\left[\mathrm{NH}_{3}\right] \rightarrow b \mathrm{CH}_{H X} \mathrm{O}_{O X} \mathrm{~N}_{N X}+c \mathrm{CO}_{2}+d \mathrm{H}_{2} \mathrm{O}$ (glucose oxidation)

$\mathrm{C}_{6} \mathrm{H}_{12} \mathrm{O}_{6}+g N X\left[\mathrm{NH}_{3}\right] \rightarrow g \mathrm{CH}_{H X} \mathrm{O}_{O X} \mathrm{~N}_{N X}+h \mathrm{CO}_{2}+i \mathrm{H}_{2} \mathrm{O}+j C_{2} \mathrm{H}_{6} \mathrm{O}$ (glucose fermentation)

$C_{2} H_{6} O+k \mathrm{O}_{2}+l N X\left[\mathrm{NH}_{3}\right] \rightarrow l \mathrm{CH}_{H X} \mathrm{O}_{O X} \mathrm{~N}_{N X}+m \mathrm{CO}_{2}+n \mathrm{H}_{2} \mathrm{O}$ (ethanol oxidation)

Stoichiometric coefficients $b, g$ and $/$ can be derived directly from biomass yield coefficients for glucose oxidation, glucose fermentation and ethanol oxidation ( $Y_{\mathrm{xg}}^{\mathrm{ox}}, Y_{\mathrm{xg}}^{\mathrm{ferm}}$ and $Y_{\mathrm{xe}}^{\mathrm{ox}}$, see Table 2$)$ and molecular weights of biomass, glucose and ethanol. Coefficients for the molar composition of cell mass, $H X, O X$ and $N X$ are derived from Carnicer et al. (2009). This leaves three unknown coefficients and three elemental balance equations $(\mathrm{C}, \mathrm{H}, \mathrm{O})$ for each stoichiometric equation, from which yield coefficients $\left(Y_{\mathrm{og}}^{\mathrm{ox}}=0.43 \frac{g_{O 2}}{g_{\text {glu }}}, Y_{\mathrm{eg}}^{\mathrm{ferm}}=0.48 \frac{g_{e}}{g_{\text {glu }}}\right.$ and $\left.Y_{\mathrm{oe}}^{\mathrm{ox}}=1.88 \frac{g_{O 2}}{g_{e}}\right)$ can be solved.

The model equations are presented below. In brief, the model consists of equations for the specific uptake rate of glucose by oxidative (1) or fermentative (2) metabolism and ethanol by oxidative metabolism (3) by Monod-type equations including also the effect of dissolved oxygen concentration for oxidative metabolism and glucose inhibition of ethanol consumption. The corresponding specific growth rates (4) - (6), and oxygen consumption from oxidation of glucose and ethanol (7) - (8) are calculated using the yield coefficients. Mass balance equations for glucose, ethanol, cell mass and dissolved oxygen concentrations are presented in equations (9) - (11). 


$$
\begin{aligned}
& q_{\mathrm{g}}^{\mathrm{ox}}=\frac{\mu_{\mathrm{max}}^{\mathrm{ox}}}{Y_{\mathrm{xg}}^{\mathrm{ox}}} \frac{c_{\mathrm{g}}}{c_{\mathrm{g}}+K_{\mathrm{g}}} \frac{c_{\mathrm{o}}}{c_{\mathrm{o}}+K_{\mathrm{o}}} \\
& q_{\mathrm{g}}^{\mathrm{ferm}}=\frac{\mu_{\mathrm{max}}^{\mathrm{ferm}}}{Y_{\mathrm{xg}}^{\mathrm{ferm}}} \frac{c_{\mathrm{g}}}{c_{\mathrm{g}}+K_{\mathrm{g}}}\left(1-\frac{c_{\mathrm{o}}}{c_{\mathrm{o}}+K_{\mathrm{o}}}\right) \\
& q_{\mathrm{e}}^{\mathrm{ox}}=\frac{\mu_{\mathrm{max}}^{\mathrm{e}}}{Y_{\mathrm{xe}}^{\mathrm{ox}}} \frac{c_{\mathrm{e}}}{c_{\mathrm{e}}+K_{\mathrm{e}}} \frac{K_{\mathrm{i}}}{c_{\mathrm{g}}+K_{\mathrm{i}}} \frac{c_{\mathrm{o}}}{c_{\mathrm{o}}+K_{\mathrm{o}}} \\
& \mu_{\mathrm{g}}^{\mathrm{ox}}=q_{\mathrm{g}}^{\mathrm{ox}} Y_{\mathrm{xg}}^{\mathrm{ox}} \\
& \mu_{\mathrm{g}}^{\mathrm{ferm}}=q_{\mathrm{g}}^{\mathrm{ferm}} Y_{\mathrm{xg}}^{\text {ferm }} \\
& \mu_{\mathrm{e}}^{\mathrm{ox}}=q_{\mathrm{e}}^{\mathrm{ox}} Y_{\mathrm{xe}}^{\mathrm{ox}} \\
& q_{\mathrm{o}}^{\mathrm{g}}=q_{\mathrm{g}}^{\mathrm{ox}} Y_{\mathrm{og}}^{\mathrm{ox}} \\
& q_{\mathrm{o}}^{\mathrm{e}}=q_{\mathrm{e}}^{\mathrm{ox}} Y_{\mathrm{oe}}^{\mathrm{ox}} \\
& \frac{d c_{i}}{d t}=\frac{F_{\text {in }}}{V} c_{i, \text { in }}-\frac{F_{\text {out }}}{V} c_{i}-\left(q_{i}^{\mathrm{ox}}+q_{i}^{\mathrm{ferm}}\right) c_{\mathrm{x}} \\
& \frac{d c_{\mathrm{x}}}{d t}=\frac{F_{\text {in }}}{V} c_{\mathrm{x}, \text { in }}-\frac{F_{\text {out }}}{V} c_{\mathrm{x}}-\left(\mu_{\mathrm{g}}^{\mathrm{ox}}+\mu_{\mathrm{g}}^{\mathrm{ferm}}+\mu_{\mathrm{e}}^{\mathrm{ox}}\right) c_{\mathrm{x}} \\
& \frac{d c_{\mathrm{o}}}{d t}=k_{\mathrm{L}} a\left(c_{\mathrm{o}}^{\mathrm{sat}}-c_{\mathrm{o}}\right)-\left(q_{\mathrm{o}}^{\mathrm{g}}+q_{\mathrm{o}}^{\mathrm{e}}\right) c_{\mathrm{x}} \\
& c_{\mathrm{o}}^{\mathrm{sat}}=\frac{p_{\mathrm{o}}}{k_{\mathrm{H}}}
\end{aligned}
$$

203 Where $q_{i}$ is specific rate of component $i\left(g_{i} g_{x}{ }^{-1} h^{-1}\right)$ and $x, g$, e and o denote cells, glucose, ethanol 204 and oxygen, respectively. Parameters $\mu_{\max }, Y$ and $K$ are listed in Table $2, c_{i}$ is concentration of 205 component $i(\mathrm{~g} / \mathrm{l}), F$ is flow rate $(\mathrm{I} / \mathrm{h})$ and $V$ is liquid volume $(\mathrm{I})$. For continuous cultivations $F_{\text {in }}=F_{\text {out }}$ $206=F$, and dilution rate $D=F / V \cdot c_{0}{ }^{\text {sat }}$ is the saturation concentration of oxygen in liquid, $p_{\mathrm{o}}$ is the partial 207 pressure of oxygen in the gas phase and $k_{H}$ is Henry's constant for oxygen in water. 
Table 2. Parameters used in the growth model of Pichia pastoris

\begin{tabular}{|c|c|c|c|}
\hline Parameter & Dimension & Value & Reference \\
\hline$\mu_{\max }^{\mathrm{ox}}$ & $h^{-1}$ & 0.18 & Solà et al. (2004) \\
\hline$\mu_{\max }^{\mathrm{ferm}}$ & $h^{-1}$ & 0.058 & This work, adjusted \\
\hline$\mu_{\max }^{\mathrm{e}}$ & $h^{-1}$ & 0.15 & This work, adjusted \\
\hline$Y_{\mathrm{xg}}^{\mathrm{ox}}$ & $g_{\text {cells }} g_{g l u}{ }^{-1}$ & 0.49 & Sonnleitner and Käppeli (1986) \\
\hline$Y_{\mathrm{xg}}^{\mathrm{ferm}}$ & $g_{\text {cells }} g_{g l u}{ }^{-1}$ & 0.05 & Sonnleitner and Käppeli (1986) \\
\hline$Y_{\mathrm{xe}}^{\mathrm{ox}}$ & $\mathrm{g}_{\text {cells }} \mathrm{g}_{\text {etoh }}{ }^{-1}$ & 0.57 & Sonnleitner and Käppeli (1986) \\
\hline$K_{\mathrm{g}}$ & $\mathrm{gglu}_{\mathrm{u}} \mathrm{I}^{-1}$ & 0.1 & Sonnleitner and Käppeli (1986) \\
\hline$K_{\mathrm{o}}$ & $\mathrm{mg}_{\mathrm{O} 2} \mathrm{l}^{-1}$ & 0.109 & This work, adjusted \\
\hline$K_{\mathrm{e}}$ & $\left.g_{\text {etoh }}\right|^{-1}$ & 0.1 & Sonnleitner and Käppeli (1986) \\
\hline$K_{i}$ & $\mathrm{gglu}_{\mathrm{g}} \mathrm{I}^{-1}$ & 0.1 & Sonnleitner and Käppeli (1986) \\
\hline$H X$ & $\mathrm{~mol}_{\mathrm{H}} \mathrm{mol}_{\mathrm{C}}^{-1}$ & 1.69 & Carnicer et al. (2009) \\
\hline$O x$ & $\mathrm{~mol}_{\mathrm{O}} \mathrm{mol}_{\mathrm{c}}^{-1}$ & 0.592 & Carnicer et al. (2009) \\
\hline$N X$ & $\mathrm{~mol}_{\mathrm{N}} \mathrm{mol}_{\mathrm{c}}^{-1}$ & 0.139 & Carnicer et al. (2009) \\
\hline
\end{tabular}

211 Literature data from continuous cultivations were used to determine model parameters either 212 directly or by fitting the model to the data. Literature experiments included in this study were 213 conducted with dilution rates between $0.1-0.16 h^{-1}$, inlet glucose concentration between $8-50$ $214 \mathrm{~g} / \mathrm{l}$, and inlet gas with varying oxygen content ranging from 5.9\% to 21\% (Baumann et al., 2008, 215 2010; Carnicer et al., 2012; Solà et al., 2004). A total of 11 experiments were included, and the 216 responses used for parameter estimation were steady state concentrations for ethanol and cell 217 mass, which were either directly reported in the references or estimated from the reported specific 218 rates (see Table 3 ). In addition, relative $k_{\llcorner} a$-values for the reactors were estimated based on the 219 stirrer speed, gas flow and reactor geometry reported in the references. An additional coefficient to 220 scale the dimensionless $k\llcorner a$ was estimated along with the growth parameters. 
Table 3. Experimental setup in the literature references. Relative mass transfer coefficient values are estimated based on the reported reactor geometry and operational conditions (agitation, aeration). Steady state concentration of cell mass and glucose are calculated from the reported specific rates if not directly given in the reference $\left({ }^{*}\right)$.

\begin{tabular}{lcccccc}
\hline & $\begin{array}{c}k_{\mathrm{L}} a \\
\text { (relative) }\end{array}$ & $\begin{array}{c}\mathrm{O}_{2} \text { in } \\
\text { gas } \\
\%\end{array}$ & $\begin{array}{c}D \\
\mathrm{~h}-1\end{array}$ & $\begin{array}{c}c_{\mathrm{glu}, \text { in }} \\
\mathrm{g} / \mathrm{l}\end{array}$ & $\begin{array}{c}c_{\mathrm{x}} \\
\mathrm{g} / \mathrm{l}\end{array}$ & $\begin{array}{c}c_{\mathrm{e}} \\
\mathrm{g} / \mathrm{l}\end{array}$ \\
\hline (Carnicer et al., 2012) & 0.2 & 21 & 0.10 & 8 & $3.86^{*}$ & $0^{*}$ \\
& 0.2 & 11 & 0.10 & 8 & $3.05^{*}$ & $0.43^{*}$ \\
(Solà et al., 2004) & 0.2 & 8 & 0.10 & 8 & $2.28^{*}$ & $0.88^{*}$ \\
(Baumann et al., 2010) & 0.4 & 21 & 0.16 & 10 & $5.42^{*}$ & 0 \\
& 1 & 21 & 0.10 & 50 & 23.98 & 0 \\
(Baumann et al., 2008) & 1 & 11 & 0.10 & 50 & 22.54 & 0.89 \\
& 1 & 8 & 0.10 & 50 & 12.58 & 6.85 \\
& 1 & 21 & 0.10 & 50 & 23.97 & 0.25 \\
& 1 & 11 & 0.10 & 50 & 22.56 & 0.68 \\
& 1 & 8.4 & 0.10 & 50 & 12.96 & 5.61 \\
& & 5.9 & 0.10 & 50 & 12.03 & 5.78
\end{tabular}

\section{$226 \quad 3.2$ Reactor model}

227 The growth model presented in the previous section assumed perfect mixing of gas and liquid 228 phases and no depletion of the oxygen in gas phase. Laboratory scale cultivations are usually carried 229 out at a relatively high gas flow rate when calculated per volume of liquid phase (VVM). Therefore, 230 the gas phase residence time is short, and depletion of oxygen from the gas phase can often be 231 ignored. However, if the gas flow rate is scaled up by using a superficial gas flow rate $\left(v_{s}, \mathrm{~m} / \mathrm{s}\right)$, the 232 VVM-value decreases during scale-up, particularly for tall vessels with a high aspect ratio (Nauha et 233 al., 2015). Thus, gas phase residence time increases and gas phase depletion may become 234 significant. In addition, hydrostatic pressure may be significant in tall vessels adding approximately 235 one bar for every $10 \mathrm{~m}$ of liquid height. This, on the other hand, increases the driving force for mass 236 transfer described in equation (12). Also, the distribution of agitation power, affecting mass transfer 237 characteristics, such as liquid side mass transfer coefficient $\left(k_{\mathrm{L}}\right)$, bubble size $\left(d_{\mathrm{b}}\right)$, and gas hold-up $(\phi)$ 238 is uneven and the gradients increase with scale. 


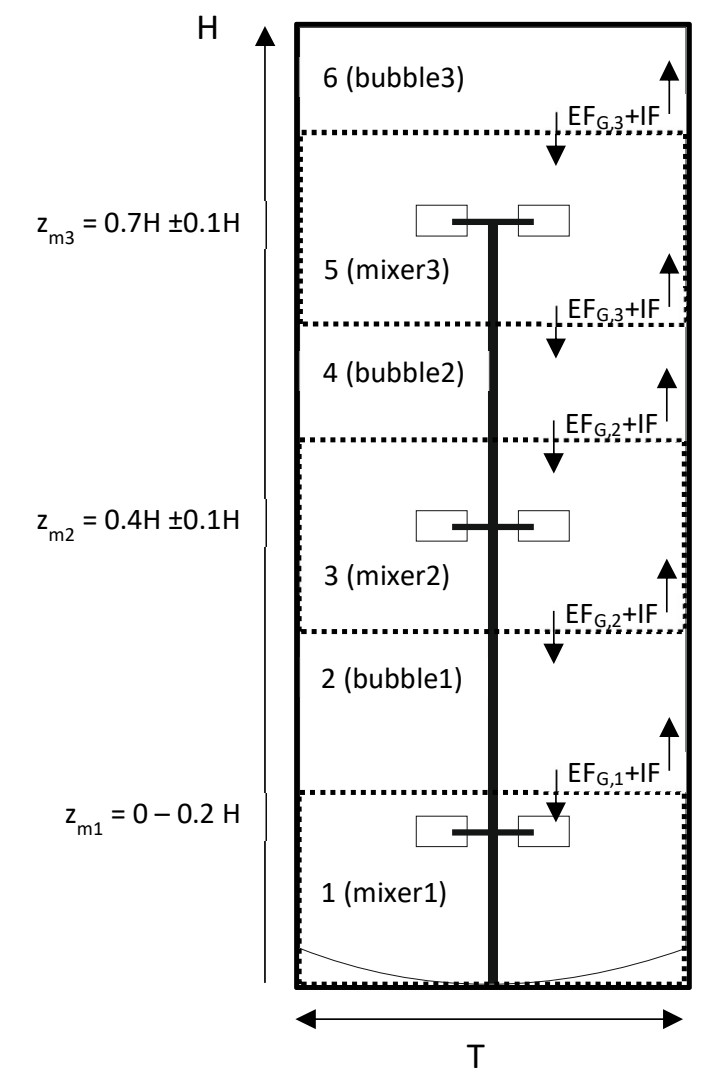

Figure 2. Schematic presentation of reactor scale model. The reactor is divided to three mixer and three bubble compartments, a total of six zones (j). Mass transfer coefficient and gas hold-up are estimated separately for each zone by equations (13)-(18), and the flow between compartments $\left(\mathrm{EF}_{\mathrm{G}}+\mathrm{IF}\right)$ is calculated by equations (21)-(22).

243 In the reactor scale model, the reactor is divided into six zones - three mixer zones and three bubble 244 zones between the impellers (Figure 2). Thus, it is applicable for STR with three impellers, and the 245 zones around and between the impellers can be expressed separately. For mixer zones $(j=1,3,5)$, 246 mass transfer and gas hold-up values are calculated based on volumetric power input and superficial 247 gas velocity (equations (13) - (16)), whereas for bubble zones $(j=2,4,6)$ the values are calculated 248 based on superficial gas velocity only (equations (17) - (18)). The mixer zone values are estimated 249 as follows. Liquid side mass transfer coefficient $k_{\mathrm{L}}$, mass-transfer area $a$ and bubble diameter $d_{\mathrm{b}}$ in 250 the homogeneous regime are estimated from equations in Nauha et al. (2015, eq22, 13 and 21) and 251 hold-up $\phi$ from equation in Vrábel et al. (2000, eq17).

$$
k_{\mathrm{L}, j}=0.301 \sqrt{D_{L}}\left(\frac{\left(\frac{P}{V}\right)_{j}}{\eta_{l i q}}\right)^{0.25}
$$




$$
\begin{aligned}
& a_{j}=\frac{6 \phi_{j}}{d_{\mathrm{b}, j}} \\
& d_{\mathrm{b}, j}=0.7 \frac{\sigma^{0.6}}{(P / V)_{j}^{0.4} \rho_{\mathrm{l}}^{0.2}}\left(\frac{\eta_{\mathrm{liq}}}{\eta_{\mathrm{gas}}}\right)^{0.1} \\
& \phi_{j}=0.37(P / V)_{j}^{0.16} v_{\mathrm{s}}^{0.55}
\end{aligned}
$$

252 where $D_{\mathrm{L}}$ is the diffusion coefficient for oxygen in water $\left(1.97 \mathrm{e}-9 \mathrm{~m}^{2} \mathrm{~s}^{-1}\right)$ and $\eta$ is viscosity (Pa s). The 253 effect of mixer power input on gas hold-up in the large $\left(>10 \mathrm{~m}^{3}\right)$ scale is much lower compared to 254 the laboratory scale $(<100 \mathrm{I})$, and the exponent on $(P / V)$ can be over 0.3 on the laboratory scale 255 compared to 0.16 used in the present calculations (Vrábel et al., 2000). For the area between 256 mixers - the so-called bubble region-hold-up is estimated from Nauha et al. $\left(2015\right.$, eq11) and $k_{\llcorner} a$ 257 from Oosterhuis and Kossen (1984, eq4).

$$
\begin{aligned}
& \phi_{j}=\frac{v_{\mathrm{s}}}{U_{\mathrm{T}}} \\
& k_{\mathrm{L}} a_{j}=0.3 v_{\mathrm{s}}^{0.7}
\end{aligned}
$$

$258 U_{T}$ is the terminal velocity of the bubbles, which is assumed to be constant $\left(0.2 \mathrm{~m} \mathrm{~s}^{-1}\right.$, Nauha et al., 259 2015). However, if the hold-up or $k_{\llcorner} a$ estimated from the mixer zone equations is lower compared 260 to the bubble zone, the bubble zone values are also used for the (particular) mixer zone. When 261 calculating the mass transfer rate in the compartment $i, k_{\llcorner} a_{i}\left(C_{0, i}{ }^{\text {sat }}-C_{0}\right)$, the value for $C_{0, i}$ sat is affected 262 by the partial pressure of oxygen in the gas phase. The residence time of the gas phase in 263 compartment $i\left(\tau_{\mathrm{i}}\right)$ is dependent on the gas volume in the compartment and the volumetric gas flow 264 rate $\left(F_{\text {gas }}\right)$.

265

$$
\begin{aligned}
& c_{0, j}^{\mathrm{sat}}=\frac{y_{0, \mathrm{gas}, j}\left(P_{\mathrm{h}}+\rho g\left(H-z_{j}\right)\right)}{k_{\mathrm{H}}} \\
& \tau_{j}=\frac{V_{j} \phi_{j}}{F_{\text {gas }}}
\end{aligned}
$$


266 The effect of liquid mixing was estimated by compartment modelling approach. The model 267 presented here is simplified from the one presented in (Vrábel et al., 2000) and it is one dimensional 268 accounting for the axial dimension. Thus, circulation flow within the compartments around each 269 stirrer and between stirrers are omitted, and the model consists of exchange flow in gassed 270 conditions $\left(\mathrm{EF}_{\mathrm{G}}\right)$ and induced flow (IF) between the compartments as shown in Figure 2. For the 271 Rushton turbine geometry:

$$
\begin{aligned}
& E F_{G}=0.34 \alpha T^{2} D^{1 / 3}(1-\varepsilon)\left[\frac{\left(P_{G} / P\right) N_{P} N^{3} D^{5}}{0.25 \pi T^{2} H_{i}(1-\varepsilon)}\right] \\
& I F=0.07 A_{\text {gap }}\left[1-(D / T)^{2}\right]^{-4.75} \frac{Q_{g}}{\left(\frac{P_{g}}{P}\right)^{\beta} N D^{3}}
\end{aligned}
$$

272 where $\alpha=0.07 \mathrm{~m} / \mathrm{s}$ and $\beta=0.3$ are model parameters, $A_{\text {gap }}$ is the area of the gap between vessel 273 wall and impeller sweep area, and $H_{\mathrm{i}}$ is the height of the impeller region (Figure 2). The mass balance 274 equations (9)-(11) were modified to include the flow between the compartments $\left(\mathrm{EF}_{\mathrm{G}}+\mathrm{IF}\right)$, and 275 local values for mass transfer coefficient and gas hold-up. In addition the gas phase oxygen content 276 (23) was included, and the saturation concentration for oxygen in liquid was calculated based on 277 the hydrostatic pressure and gas phase oxygen content.

$$
\frac{d c_{0, \text { gas }, j}}{d t}=\frac{c_{\mathrm{o}, \mathrm{gas}, \mathrm{j}-1}-c_{\mathrm{o}, \mathrm{gas}, j}}{\tau_{j}}-\frac{k_{\mathrm{L}} a_{j}}{\phi_{j}}\left(c_{\mathrm{o}, j}^{\mathrm{sat}}-c_{\mathrm{o}}\right)
$$

278 Where $c_{0, \text { gas, }}$ is the oxygen concentration in the gas phase of compartment $j$ and $j=0$ for the inlet 279 gas.

\section{Results and discussion}

\subsection{Yeast cultivations}

282 The yeast cultivations were carried out with a constant stirrer speed and gas flow rate, which 283 resulted in low dissolved oxygen concentrations during growth on glucose in both reactors (Figure 284 3). Thus, significant amounts of ethanol were produced in both cultivations towards the end of the 285 glucose phase, which lasted about $21 \mathrm{~h}$. The peak ethanol concentrations before ethanol consumption phase were 14.6 and $12.5 \mathrm{~g} / \mathrm{I}$ for Rushton and OKTOP ${ }^{\circledR}$-geometries, respectively. The 
287 lower ethanol concentration in the $\mathrm{OKTOP}^{\circledR}$ reactor is likely due to a higher dissolved oxygen 288 concentration. Although DO drops to about $2 \%$ at the lower probe in both reactors, it reaches such 289 a low value already at $15 \mathrm{~h}$ in the STR, whereas the limit of $2 \%$ is reached only after $20 \mathrm{~h}$ in the 290 OKTOP $^{\circledR}$ reactor. Also, DO at the probe positioned in the upper part of the reactor was higher in 291 OKTOP $^{\circledR}$ (approx. 20\% vs. 10\%). After glucose consumption, there is a short lag-phase before ethanol 292 consumption, and the fermentations were finished at about $35 \mathrm{~h}$. The cell concentrations after the 293 glucose phase were $18.5 \mathrm{~g} / \mathrm{l}$ and $19.6 \mathrm{~g} / \mathrm{l}$ and after ethanol consumption $26.8 \mathrm{~g} / \mathrm{l}$ and $29.5 \mathrm{~g} / \mathrm{l}$ for STR 294 and OKTOP$^{\circledR}$, respectively. Thus, the peak ethanol concentration was lower and final cell 295 concentration was higher in the cultivation carried out in the OKTOP ${ }^{\circledR}$ reactor. 


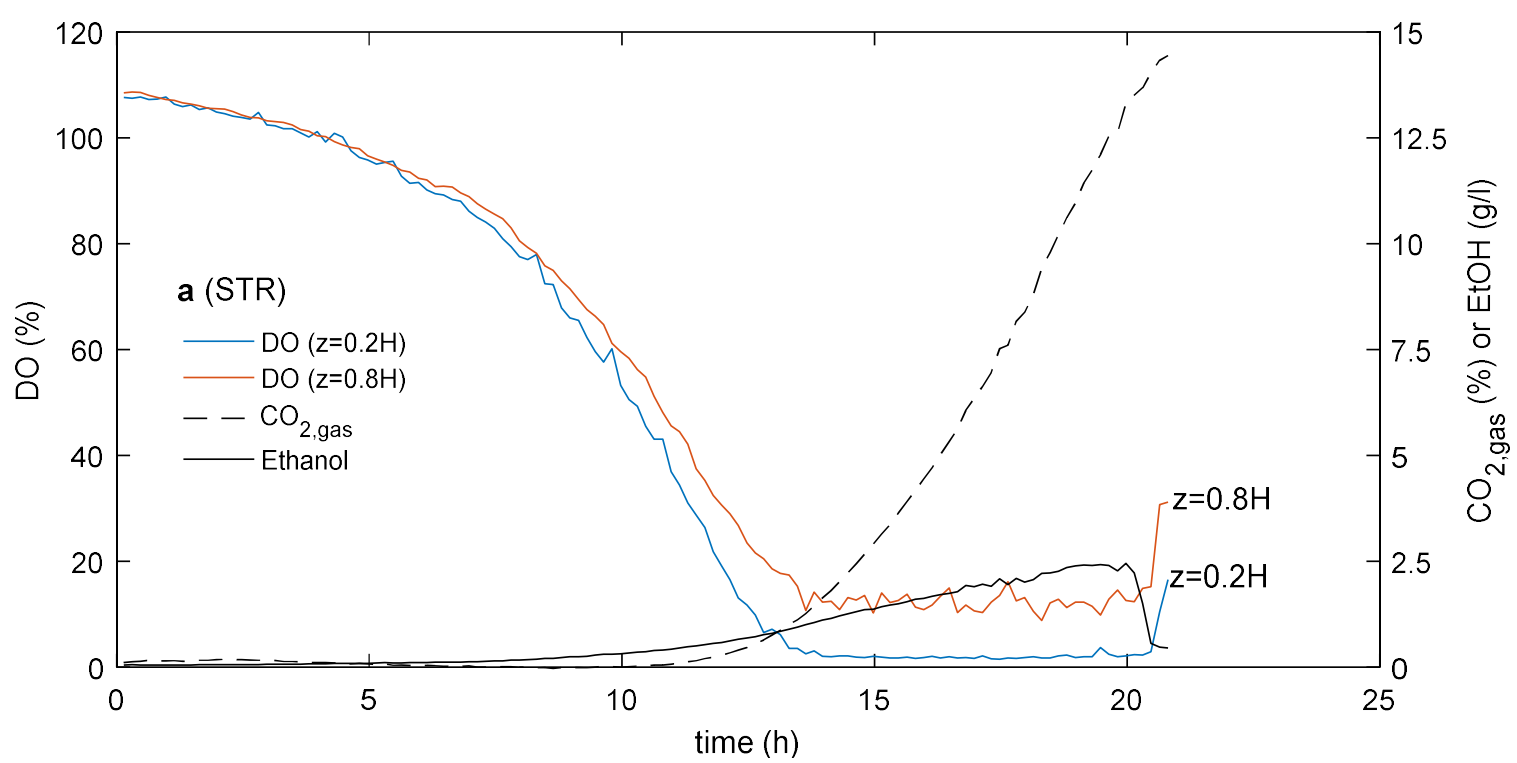

296

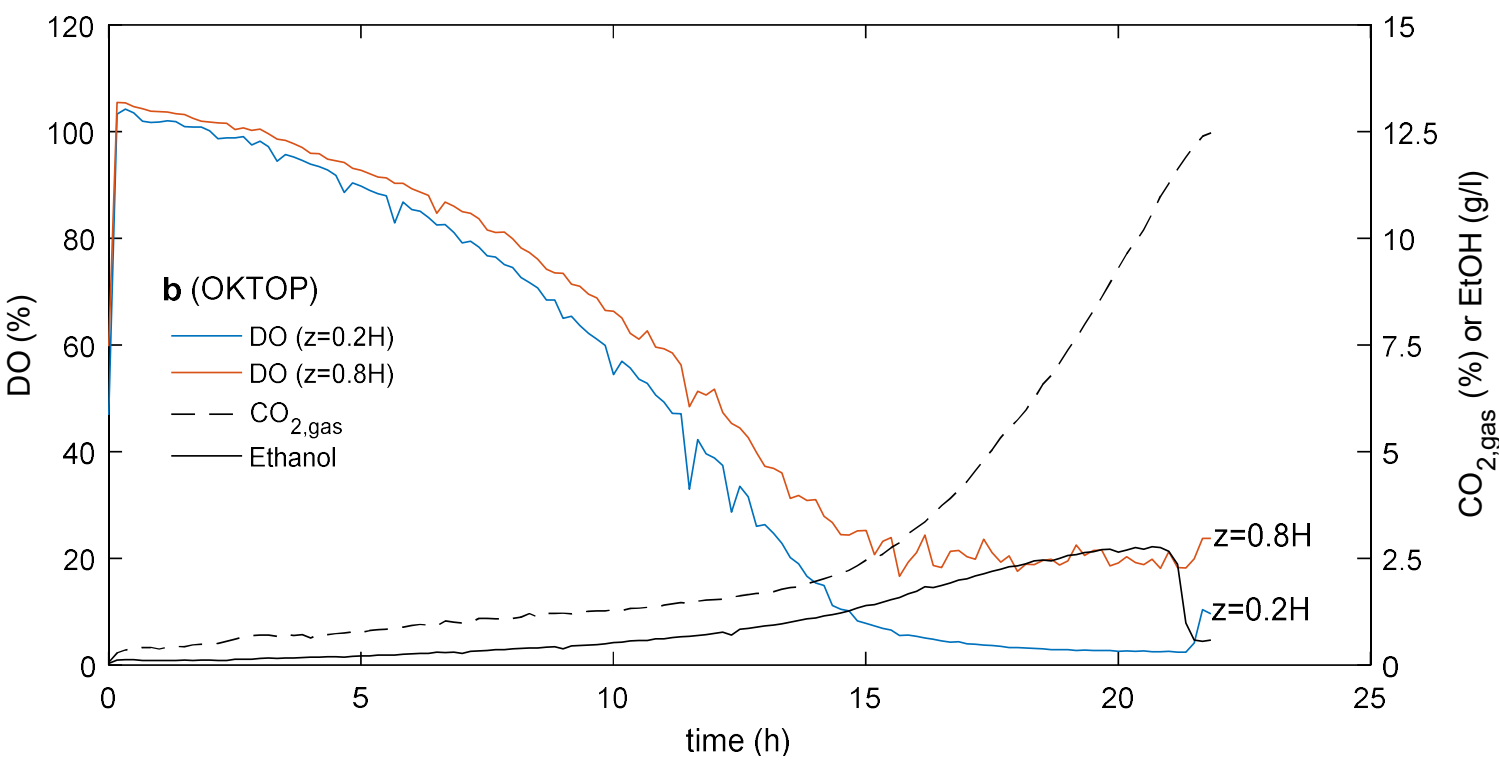

298 Figure 3. Measurement data from lab-scale cultivations a) Stirred tank reactor agitated with three Rushton turbines b) OKTOP ${ }^{\circledR}$ 299 reactor

3004.2 Growth model for Pichia pastoris

301 The model parameters were mainly from literature sources, and they are listed in Table 2. Three

302 parameters, $\mu_{\max }^{\text {ferm }}$ (maximum specific growth rate on glucose via fermentation), $\mu_{\max }^{\mathrm{e}}$ (maximum 303 specific growth rate on glucose via fermentation) and $K_{\circ}$ (saturation coefficient for oxygen uptake) 304 were estimated using data from chemostat cultivations presented in the literature in different 305 cultivation conditions (Table 3, Baumann et al., 2008, 2010; Carnicer et al., 2012; Solà et al., 2004). 
An example of the effect of inlet gas oxygen concentration is presented in Figure 4a. It can be seen 307 that in the investigated conditions, ethanol production is negligible when oxygen content of the inlet gas is above $10 \%$, and cell concentration is above $20 \mathrm{~g} / \mathrm{l}$, both of which are well predicted by

309 the model. At lower inlet gas oxygen concentrations, ethanol is produced and cell concentration 310 decreases. The model qualitatively captures the effect, although there is some deviation between 311 the data in the literature references and the model prediction. Parity plot for all experimental points 312 of steady state cell mass and ethanol concentration is presented in Figure $4 \mathrm{~b}$ and correspondence 313 between the model and experimental data is quite good.

314 The model was also applied to the batch cultivation in STR discussed in section 4.1. The initial 315 conditions were the same as in the batch experiment and $k\left\llcorner a\right.$ was estimated to be $250 \mathrm{~h}^{-1}$ in the 316 experimental conditions based on previous research (Tervasmäki et al., 2016). A lag time of one 317 hour was manually adjusted for the model prediction so that the time of glucose exhaustion is 318 roughly the same as in the experiments. The results are presented in Figure 5 for glucose, ethanol, 319 and cell mass concentrations (a), as well as for dissolved oxygen (b). The model corresponds quite 320 well with the cultivation conditions. Only the cell concentrations after the glucose consumption 321 phase are significantly over predicted, and the final cell concentration is overestimated by almost $32230 \%$. There is also a possibility that higher amounts of ethanol were produced than the measured 323 concentrations that as part of the ethanol escaped with the exhaust gas thus not accumulating in 324 the liquid. Therefore, the difference between the measured and estimated cell concentrations could 325 be due to higher peak ethanol concentration, which would lower the cell yield from glucose. 326 However, the model qualitatively captures the decrease in growth rate after switching the carbon 327 source from glucose to ethanol.

328 In addition, the dissolved oxygen concentration during the cultivation follows the same trend as the 329 measured values. The model fails to capture the short peak at $21 \mathrm{~h}$ indicating the switch in 330 metabolism from glucose to ethanol utilization. This is expected, as detailed metabolic routes were 331 not included in the model. Structured modelling approaches such as cybernetic modelling (Ho et al., 332 2015; Ramkrishna and Song, 2012), genome-scale models (GEMs) or structured kinetic models 333 (Heijnen, 2005; Kerkhoven et al., 2015) may enable more rigorous description of the observed 
phenomena. However, the goal here is to describe a model with low computational load to be 335 applied in bioreactor simulations. The short increase in the measured dissolved oxygen 336 concentration between 28 and $31 \mathrm{~h}$ was due to a temporary increase in the agitation rate, and the 337 model results were calculated with a constant $k_{\llcorner} a$ value. Based on the discussion above, it can be concluded that the model is also adequate for estimating batch culture behaviour.
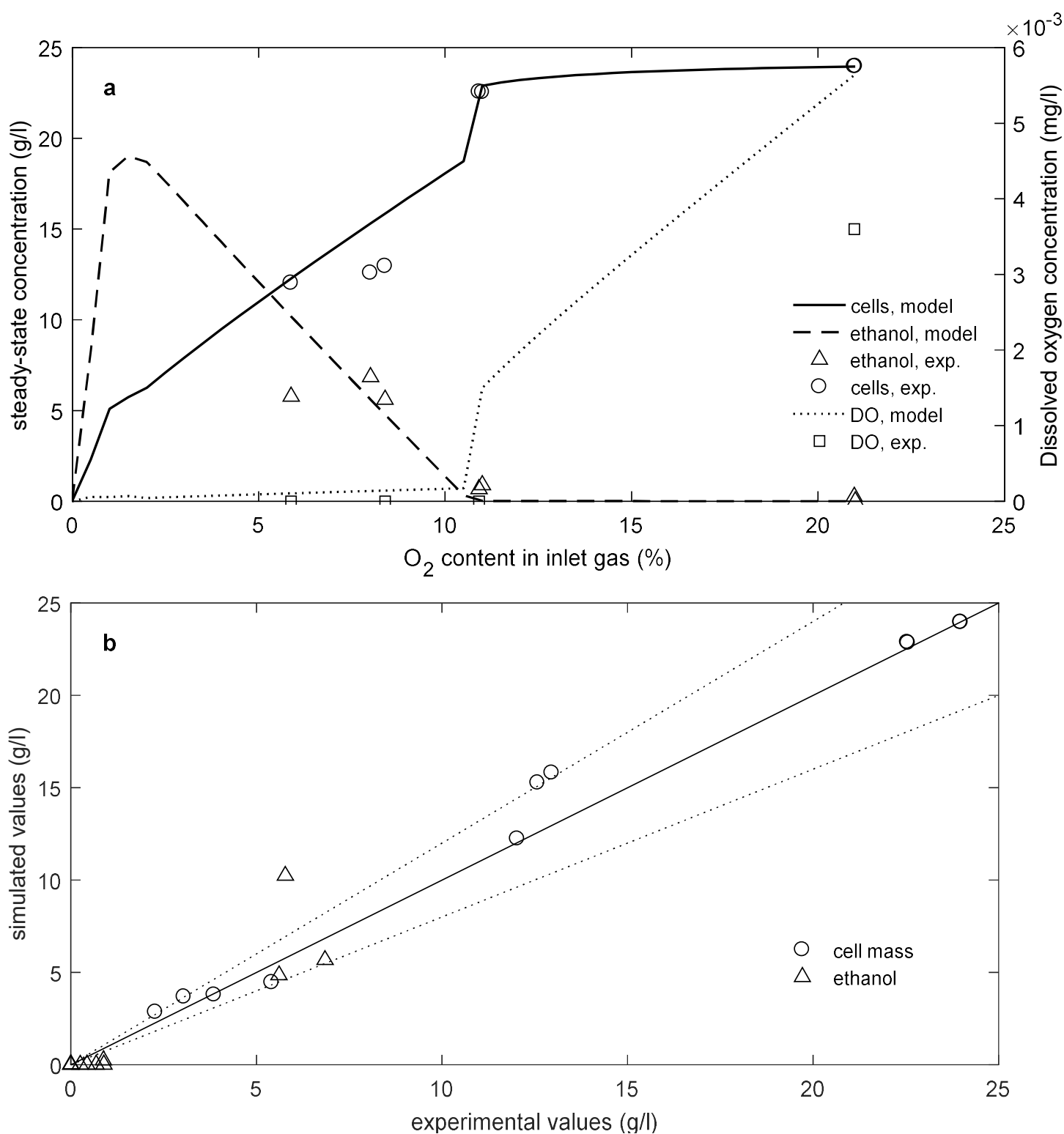

Figure 4. a) Steady-state concentration of cell mass and ethanol (experimental and simulated) and dissolved oxygen (simulated) vs. the oxygen content of inlet gas for $c_{g, i n}=50 \mathrm{~g} / \mathrm{l}$ and $\mathrm{D}=0.1 \mathrm{~h}-1$ as reported in (Baumann et al., 2008, 2010). b) Simulated and experimental values for steady-state concentration of cell mass and ethanol in all chemostat cultivation conditions in the literature, dotted lines show $+/-20 \%$ margin. 

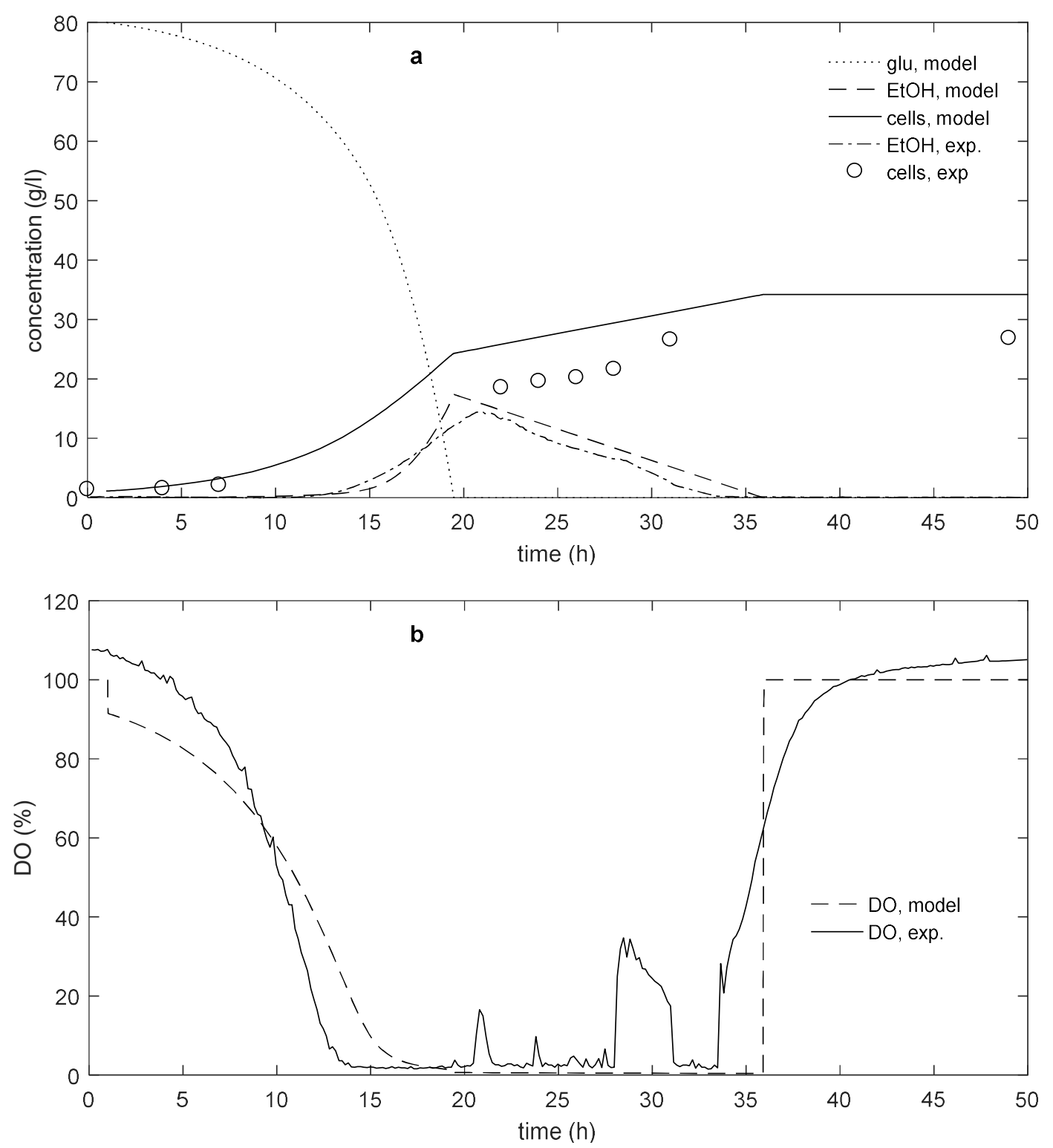

Figure 5. Comparison of model prediction to batch cultivation data in STR, additional lag time of one hour was added to the model prediction. Estimated $k_{\llcorner} a$ for the simulations was $250 \mathrm{~h}^{-1}$ a) glucose, ethanol and cell concentration b) dissolved oxygen

349 One way to study the effect of oxygen transfer on culture conditions using the model is by plotting 350 the steady-state cell mass, glucose and ethanol concentrations of a continuous cultivation as a 351 function of dilution rate $D$. This has been done in Figure $6 a$ for two $k_{\mathrm{L}} a$-values $\left(250 \mathrm{~h}^{-1}\right.$ and $\left.500 \mathrm{~h}^{-1}\right)$. 352 It can be seen that for lower $k_{\mathrm{L}} a$, the steady-state cell concentration begins to decrease when $D>$ $3530.07 \mathrm{~h}^{-1}$ and it can be explained by oxygen limitation with simultaneously occurring ethanol 354 accumulation. When the dilution rate is further increased above $0.15 \mathrm{~h}^{-1}$, culture washout occurs. 
355 In the simulation with higher mass transfer coefficient, there is very little variation in cell 356 concentrations with $D<0.16 \mathrm{~h}^{-1}$, and culture washout occurs sharply at $D>0.17 \mathrm{~h}^{-1}$. This value is 357 close to the maximum growth rate and this type of behaviour is typical for ideal continuous 358 cultivation. Thus, oxygen limitation can be detected from decreased cell yield, ethanol 359 accumulation, and washout at a lower dilution rate due to decreased growth rate.

360 The effect of $k_{\llcorner} a$ is further elucidated in Figure $6 \mathrm{~b}$, in which steady-state concentrations (cells, 361 glucose, ethanol, dissolved oxygen) are plotted with respect to $k\left\llcorner a\right.$ at $D=0.1 \mathrm{~h}^{-1}$. It can be seen that 362 the conditions are mass transfer limited when $k\left\llcorner a<400 \mathrm{~h}^{-1}\right.$, which can be seen as low dissolved 363 oxygen concentration and accumulation of ethanol. Increasing the mass transfer rate further 364 increases the dissolved oxygen concentration, but has no effects on cell concentration if the critical 365 value is exceeded. This is a very similar situation to the one presented for the data in the literature 366 in Figure 4 for inlet gas oxygen concentration as both parameters ( $k_{\llcorner} a$ and gas composition) directly 367 affect the oxygen transfer rate.

368 The model sensitivity to parameters was assessed by calculating the relative change in glucose, 369 ethanol, cell, and dissolved oxygen concentrations when each parameter was increased by $10 \%$ 370 from the values presented in Table 2. The results are presented in Figure 7 in which the sensitivities 371 are plotted as heat maps with $c_{\mathrm{glu}, \mathrm{in}}=40 \mathrm{~g} / \mathrm{l}, D=0.1 \mathrm{~h}^{-1}(\mathrm{a}-\mathrm{b})$ or $D=0.15 \mathrm{~h}^{-1}(\mathrm{c}-\mathrm{d})$, and $k_{\mathrm{L}} a=250 \mathrm{~h}^{-1}$ $372(\mathrm{a}, \mathrm{c})$ or $k_{\llcorner} a=500 \mathrm{~h}^{-1}(\mathrm{~b}, \mathrm{~d})$. The concentrations calculated with the optimal parameters can be seen 373 in Figure 6.

374 The model shows less sensitivity for the lower dilution rate, which can be expected when looking at 375 the data in Figure 6a. The cell washout occurs at dilution rates between $0.15-0.17 \mathrm{~h}^{-1}$, and the 376 parameter sensitivity is increased at that in that range. It should be noted that some of the 377 seemingly high sensitivity values are due to very low concentrations calculated with the optimal 378 parameters. For example, the ethanol concentrations with higher $k_{\mathrm{L}} a$-value $\left(500 \mathrm{~h}^{-1}\right)$ are below 0.06 $379 \mathrm{~g} / \mathrm{l}$ so even minor changes in the absolute concentration affect the relative values (Figure $7 \mathrm{~b}$ ). Same 380 applies for glucose although the concentrations are slightly higher between $0.1-0.5 \mathrm{~g} / \mathrm{l}$. The effect 381 of parameters describing the elemental composition of the cells ( $O X, H X$ and $N X)$ have similar effect 
382 as the yield parameters. However, the elemental composition is expected to vary less than $10 \%$

383 (Carnicer et al., 2009).

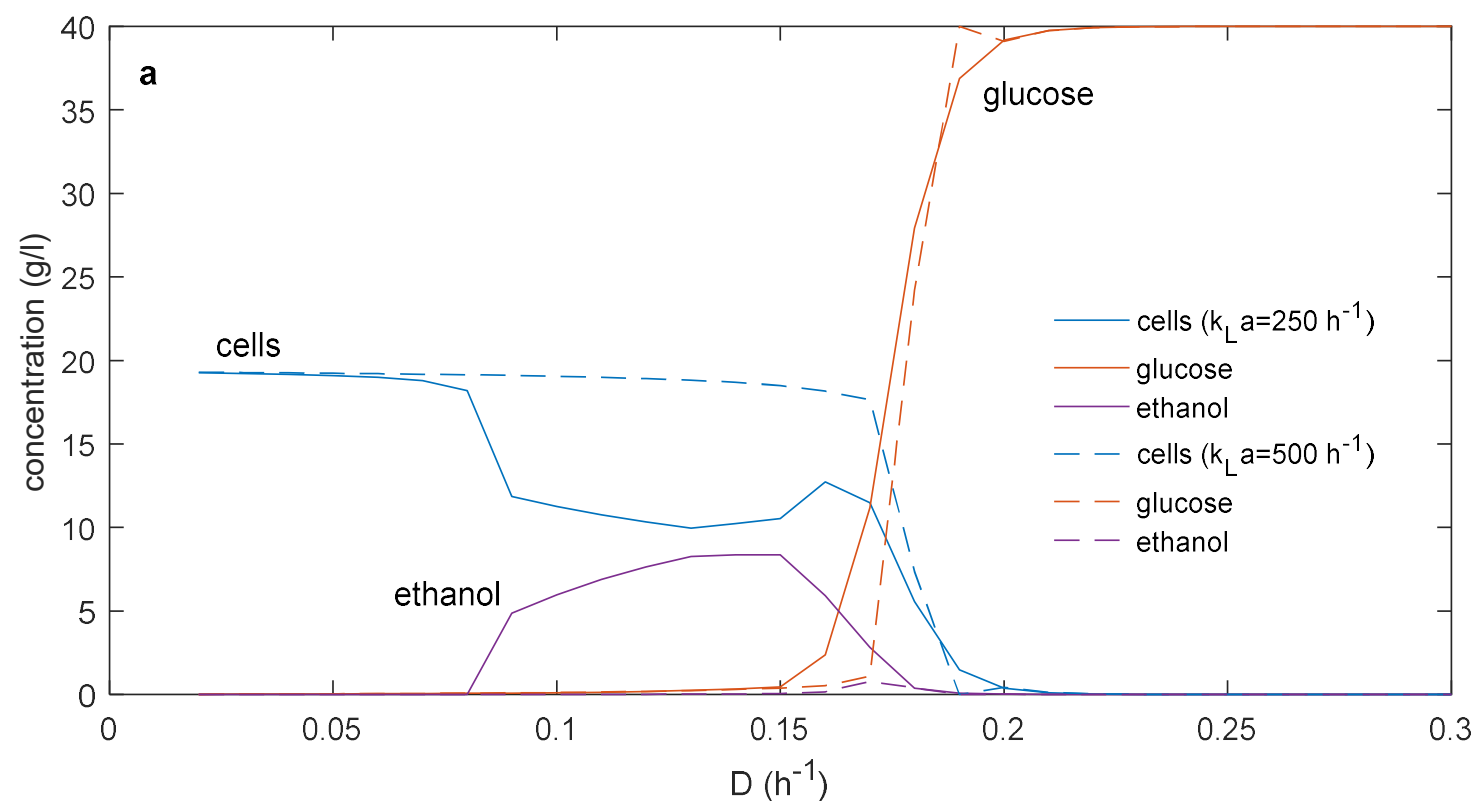

384

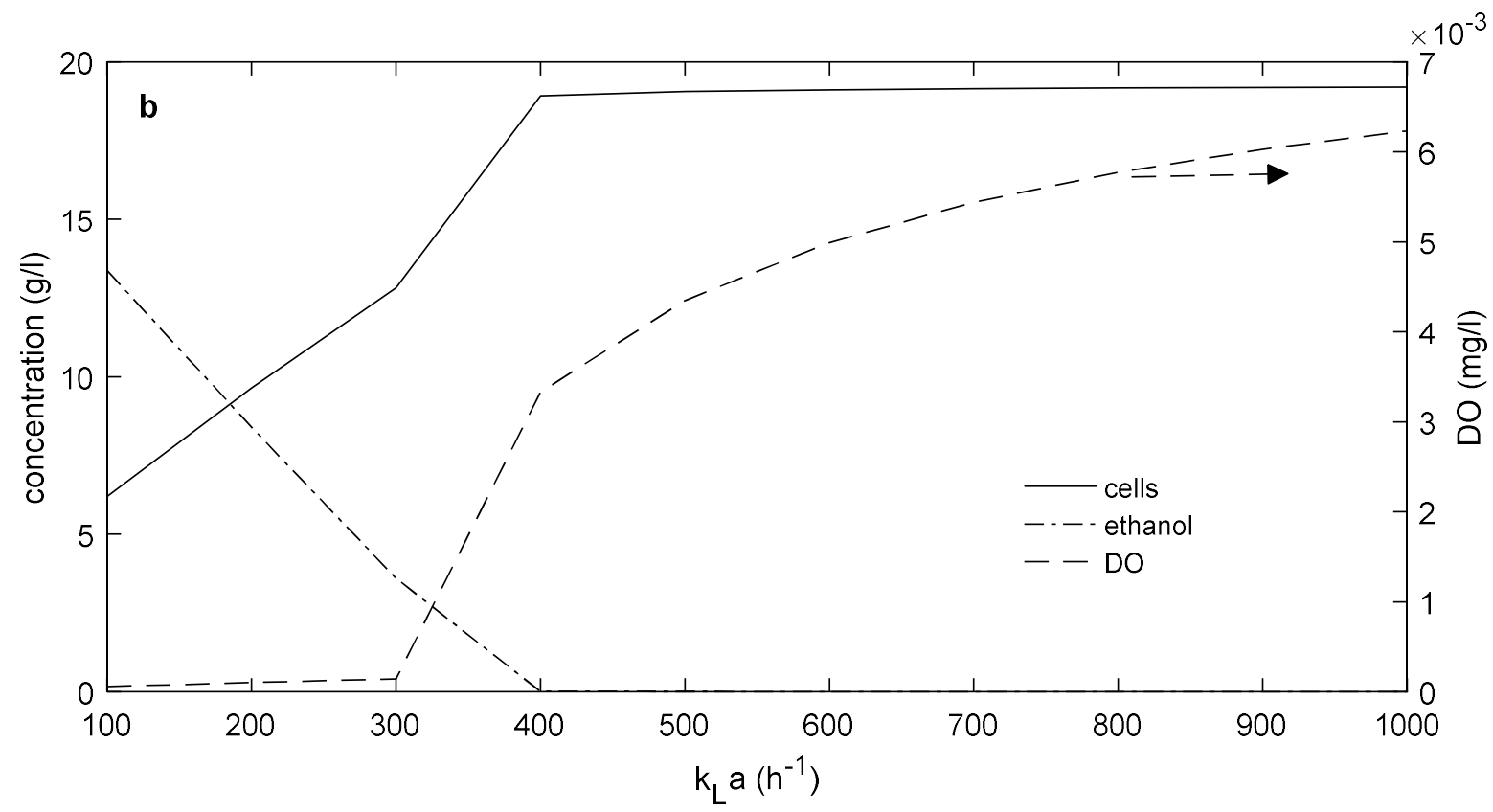

Figure 6. Steady-state concentrations for chemostat simulations with $c_{\text {glu, in }}=40 \mathrm{~g} / \mathrm{l}$. a) cells, glucose and ethanol as a function of dilution rate with $k_{\llcorner} a=250$ and $500 \mathrm{~h}^{-1}$ b) cells, ethanol and dissolved oxygen as a function of $k_{\llcorner} a$ with $D=0.1 \mathrm{~h}^{-1}$ 


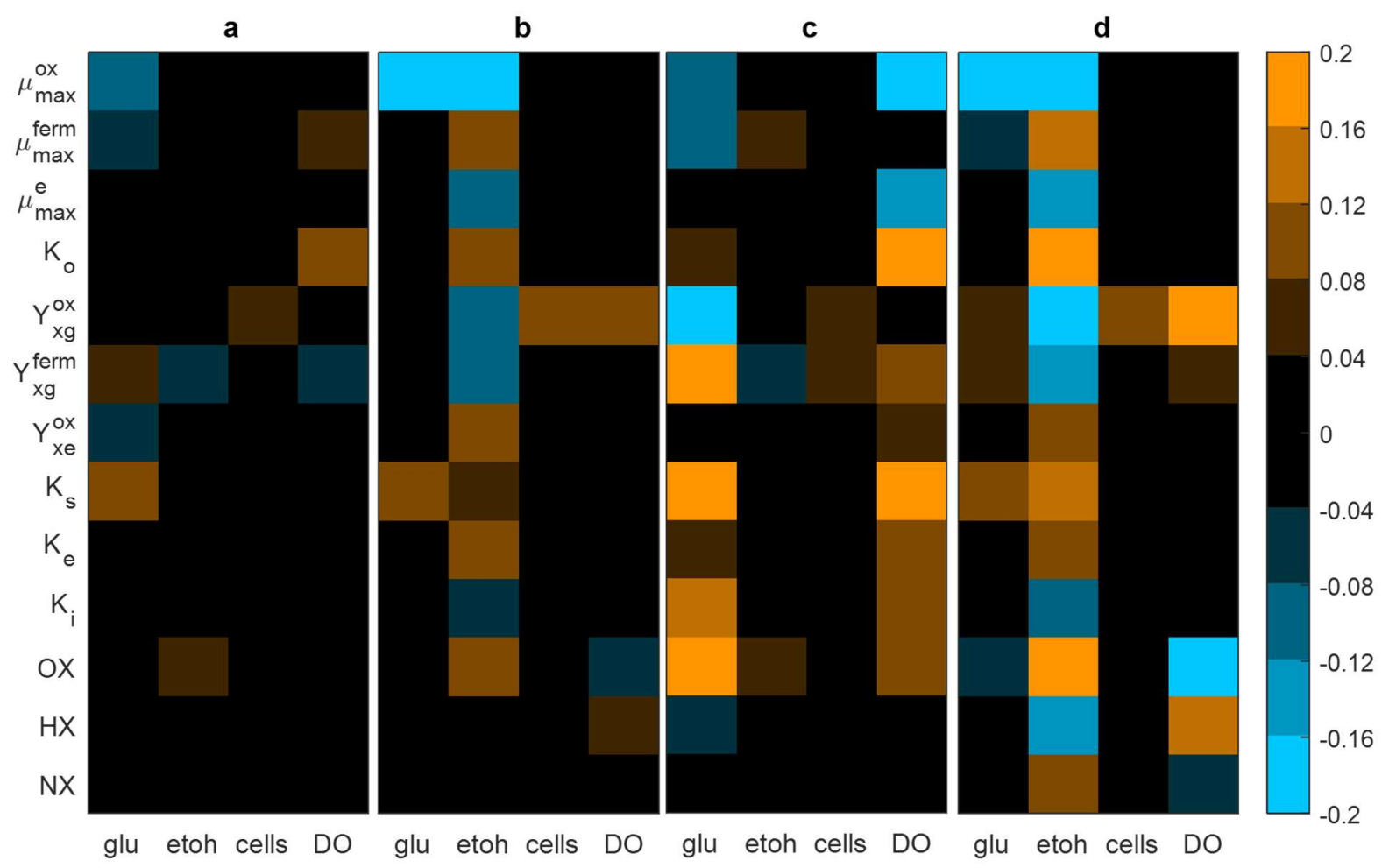

Figure 7. Parameter sensitivity of model-predicted glucose, ethanol, cell and dissolved oxygen concentrations in steady-state of chemostat operation with $c_{\mathrm{glu}, \mathrm{in}}=40 \mathrm{~g} / \mathrm{l}$. Relative change of concentrations when each parameter was increased by $10 \%$. a) $D=0.1$ $\mathrm{h}^{-1}$ and $k_{\llcorner} a=250 \mathrm{~h}^{-1}$ b) $D=0.1 \mathrm{~h}^{-1}$ and $k_{\llcorner} a=500 \mathrm{~h}^{-1}$ c) $D=0.15 \mathrm{~h}^{-1}$ and $k_{\llcorner} a=250 \mathrm{~h}^{-1}$ d) $D=0.15 \mathrm{~h}^{-1}$ and $k_{\llcorner} a=500 \mathrm{~h}^{-1}$

\subsection{Scale-up effects}

393 The simulations to study scale-up effects were made at similar conditions as in Figure $6\left(D=0.1 \mathrm{~h}^{-1}\right.$ and $\left.c_{\mathrm{glu}, \mathrm{in}}=40 \mathrm{~g} / \mathrm{l}\right)$, and the aspect ratio was fixed to $H / T=3$. Maximum gas flow was maintained at $v_{\mathrm{s}}=0.03 \mathrm{~m} / \mathrm{s}$ so that a homogeneous flow regime could be assumed, which is a prerequisite for equations (13(18). The volumetric power consumption between $250-1000 \mathrm{~W} / \mathrm{m}^{3}$ was used in the simulations. The main factor that affects the cell growth in reactors of different scale and operational conditions in the investigated domain is the dissolved oxygen concentration. The effect of scale and operational conditions on dissolved oxygen and oxygen transfer conditions are shown

400 in Figure 8 in which dimensionless axial profiles of dissolved oxygen are plotted for 10 and $1000 \mathrm{~m}^{3}$ 401 reactors with different agitation and aeration rates. In addition, the dimensionless profiles of oxygen saturation concentration, taking into account hydrostatic pressure and oxygen content of the gas phase are included in the plots to illustrate the driving force for mass transfer. 
404 In the smaller reactor $\left(10 \mathrm{~m}^{3}, a, b, e, f\right)$, the dissolved oxygen concentration is quite uniform, and 405 increasing the agitation from 250 to $1000 \mathrm{~W} / \mathrm{m}^{3}(\mathrm{~b}, \mathrm{f})$ would be sufficient to increase the dissolved 406 oxygen level and prevent fermentative metabolism due to oxygen limitation. The profile showing 407 the saturation concentration of oxygen is also quite uniform as depletion of oxygen and hydrostatic 408 pressure effects are insignificant. In larger reactor $\left(1000 \mathrm{~m}^{3}, \mathrm{c}, \mathrm{d}, \mathrm{g}, \mathrm{h}\right)$, however, the dissolved 409 oxygen and saturation curves are more curved, and values are lower at the upper part of the reactor.

410 This is due to oxygen depletion of gas phase and hydrostatic pressure effects, which both affect the 411 driving force for mass transfer. Another factor is insufficient mixing in the axial direction of the 412 dispersion allowing significant gradients for oxygen. The effect of scale is more profound when the 413 superficial gas velocity is lower, and increasing the agitation power in the large scale is not sufficient 414 to overcome these effects.
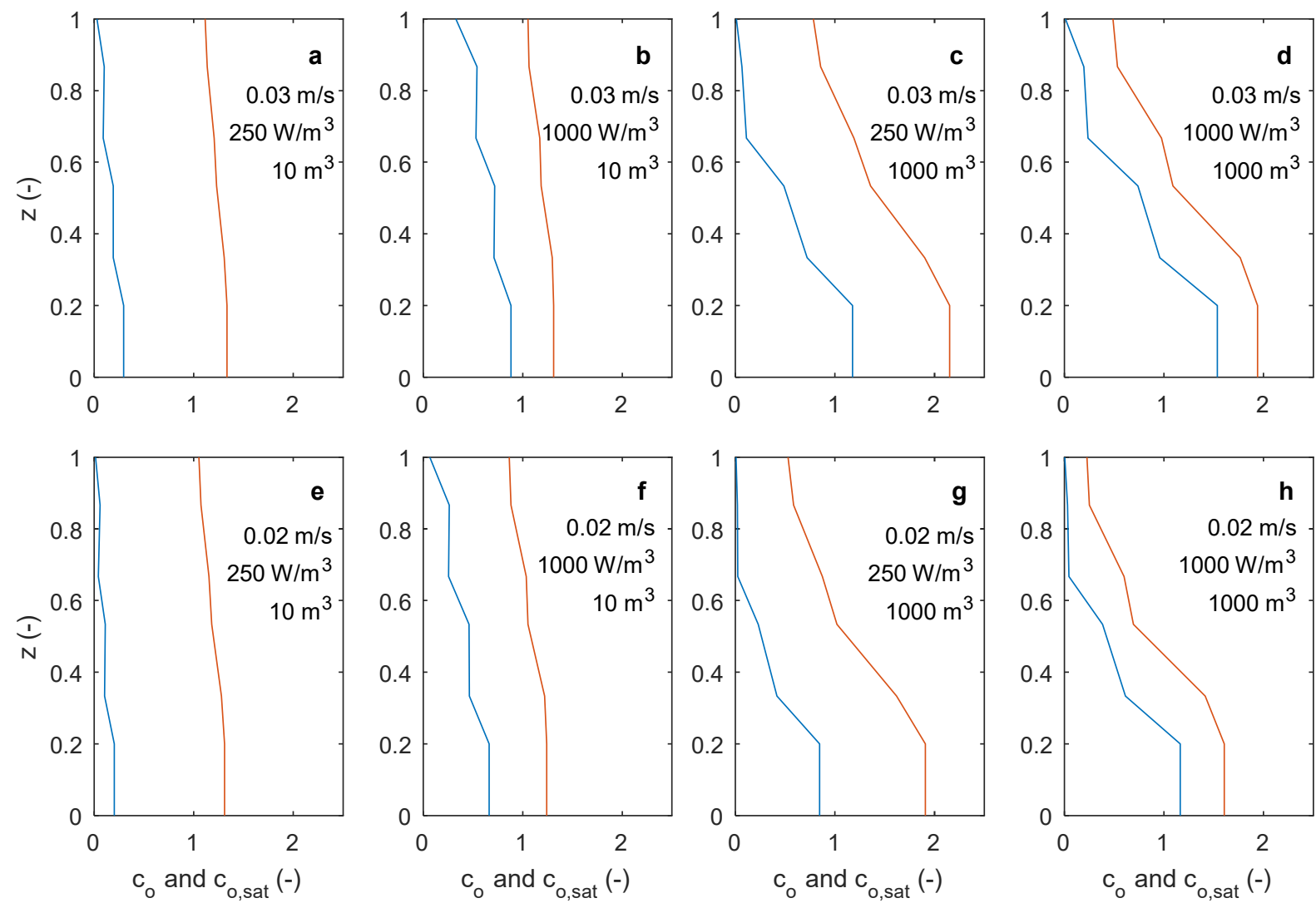

416 Figure 8. Dimensionless axial profile of dissolved oxygen (blue line, $c_{0}$ ) and saturation concentration (red line, $c_{0, \text { sat }}$ calculated based 417 on hydrostatic pressure and gas phase oxygen fraction) in STR. Corresponding cell yield is shown in Figure 9. 
418 A more general view of the effect of reactor volume and operational conditions on simulated steady419 state conditions can be seen in Figure 9 in which the steady-state concentrations of cells-are plotted 420 against the reactor volume. The cell concentrations are scaled by the theoretical maximum values 421 so that fully aerobic metabolism with highest cell yield would give a value of one. Three overall 422 volumetric power inputs $\left(250,500\right.$ and $\left.1000 \mathrm{~W} / \mathrm{m}^{3}\right)$ and two superficial gas velocities $(0.02 \mathrm{~m} / \mathrm{s}$ and $4230.03 \mathrm{~m} / \mathrm{s}$ ) are included. The conditions for which axial profiles of oxygen are plotted in Figure 8 are 424 shown in circles. It can be seen that in small reactors with the highest gas flow and power input 425 (volume averaged $k_{\llcorner} a=427 \mathrm{~h}^{-1}$ ), the cell yield is almost at its maximum, a similar situation to that in 426 Figure $6 \mathrm{~b}$ with $k_{\llcorner} a>400 \mathrm{~h}^{-1}$. With increasing scale, however, the cell yield decreases as the dissolved 427 oxygen decreases although the overall $k_{\llcorner} a$ remains constant. The decrease in cell yield is mainly due 428 to increased gas phase residence time and oxygen depletion, and the variation of dissolved oxygen 429 concentration along the reactor. It is more profound when superficial gas velocity is lower. It can 430 also be noted that the effect of power input decreases with scale as the curves with different power 431 inputs approach each other. Therefore, increasing the agitation power yields only a minor 432 improvement. 


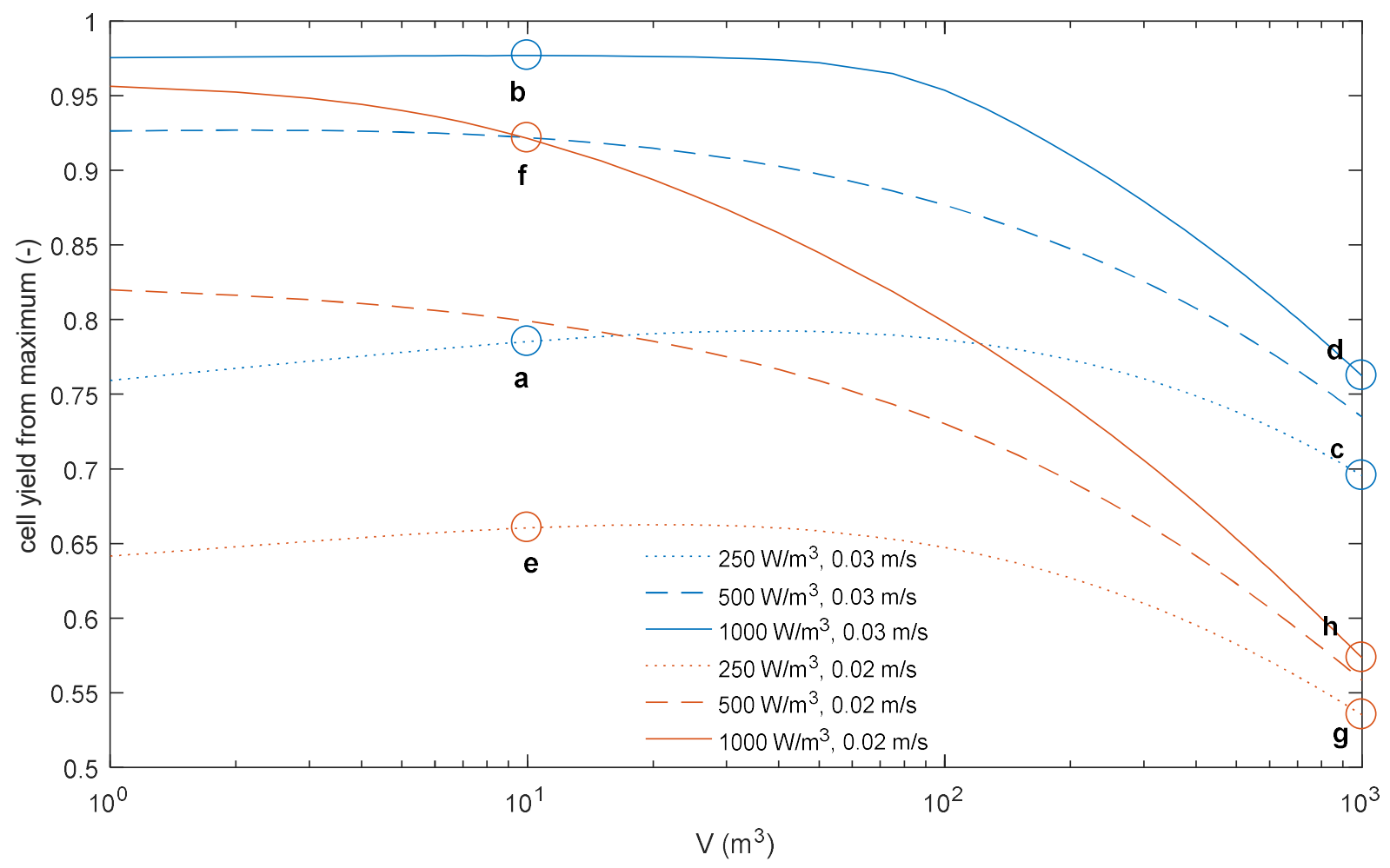

Figure 9. The effect of reactor scale (STR), gas flow and agitation power on chemostat steady state, simulations were run with, $D=$ $0.1 \mathrm{~h}^{-1}, H / T=3, c_{\mathrm{glu}, \mathrm{in}}=40 \mathrm{~g} / \mathrm{l}$. The steady-state cell concentration is scaled with theoretical maximum values for $v_{\mathrm{s}}=0.03 \mathrm{~m} / \mathrm{s}$, overall $k_{\llcorner} a$-values 164,260 and $427 \mathrm{~h}^{-1}$ for increasing power input and for $v_{\mathrm{s}}=0.02 \mathrm{~m} / \mathrm{s}$, overall $k_{\llcorner} a$-values 130,206 and $340 \mathrm{~h}^{-1}$ for increasing power input. Letters a-g mark the examples shown in Figure 8 for the axial profile of oxygen

438 Insufficient mixing of the bulk dispersion also causes detrimental effects in the large-scale 439 simulations as low dissolved oxygen concentrations, leading to fermentative metabolism, are found 440 in the upper part of the reactor. Time scales for oxygen transfer are in the range of $10-20$ seconds 441 based on the overall $k_{\llcorner} a$-values whereas mixing times are in the range of $100-200$ seconds in the 442 simulations made in $100-1000 \mathrm{~m}^{3}$ scale. Based on these simulations, improving the gas handling 443 capacity and the liquid mixing especially in the axial direction would be preferred improvements in 444 large scale reactors. The current model for liquid mixing is based on literature work validated up to 445 reactors $30 \mathrm{~m}^{3}$ so the simulation results up to $1000 \mathrm{~m}^{3}$ are indicative. Furthermore, it cannot be 446 applied for stirred draft tube reactors without determining new parameters specific for the impeller 447 and draft tube configuration. Further research is planned on more rigorous assessment of the 448 hydrodynamics of different reactor types - such as stirred tank and airlift reactors as well as large 
449 scale OKTOP $^{\circledR 9000 ~-~ a n d ~ t h e ~ a p p l i c a t i o n ~ o f ~ m i c r o b i a l ~ g r o w t h ~ k i n e t i c s ~ w i t h ~ t h e ~ m o r e ~ a c c u r a t e ~}$ estimation of hydrodynamic and mass transfer conditions.

\section{Conclusions}

452 The effect of oxygen transfer conditions on the cell growth and metabolism of Pichia pastoris was

453 studied by laboratory batch experiments and modelling the yeast growth. The model describes well 454 the effect of oxygen availability on oxidative/fermentative metabolism of the yeast, and the 455 correspondence with literature data and laboratory scale batch experiments is good on qualitative 456 basis. The scale-up effects were studied by applying the growth model with one dimensional reactor 457 scale model in which the effects of gas phase depletion, hydrostatic pressure and axial mixing of the 458 dispersion were included. The model simulations indicated a decrease in cell yield when the size of 459 the reactor was increased. The effect is mainly due to increased gas phase residence time and 460 oxygen depletion in the gas phase, and insufficient mixing of the liquid phase. These effects lead to 461 oxygen limited conditions for the yeast in some parts of the reactor and onset of fermentative 462 metabolism. On the other hand, hydrostatic pressure increases with scale, which increases the 463 partial pressure of oxygen and, thus, the driving force for mass transfer. Improvements in the gas 464 handling capacity at moderate agitator power input, and improvement of overall liquid mixing of 465 the reactor would significantly improve the reactor performance in large scale.

\section{Acknowledgements}

467 The authors acknowledge the Finnish Funding Agency for Innovation Tekes for providing financing 468 for this work (Grant number 906/312016, Tackling mass transfer challenges in fermentations). The 469 authors would also like to thank Stella Polido for her assistance in the experimental work.

\section{References}

Baumann, K., Carnicer, M., Dragosits, M., Graf, A.B., Stadlmann, J., Jouhten, P., Maaheimo, H., Gasser, B., Albiol, J., Mattanovich, D., Ferrer, P., 2010. A multi-level study of recombinant Pichia pastoris in different oxygen conditions. BMC Syst. Biol. 4, 141. https://doi.org/10.1186/1752-0509-4-141 
Baumann, K., Maurer, M., Dragosits, M., Cos, O., Ferrer, P., Mattanovich, D., 2008. Hypoxic fedbatch cultivation of Pichia pastoris increases specific and volumetric productivity of recombinant proteins. Biotechnol. Bioeng. 100, 177-183. https://doi.org/10.1002/bit.21763

Carnicer, M., Baumann, K., Töplitz, I., Sánchez-Ferrando, F., Mattanovich, D., Ferrer, P., Albiol, J., 2009. Macromolecular and elemental composition analysis and extracellular metabolite balances of Pichia pastoris growing at different oxygen levels. Microb. Cell Factories 8, 65. https://doi.org/10.1186/1475-2859-8-65

Carnicer, M., ten Pierick, A., van Dam, J., Heijnen, J.J., Albiol, J., van Gulik, W., Ferrer, P., 2012. Quantitative metabolomics analysis of amino acid metabolism in recombinant Pichia pastoris under different oxygen availability conditions. Microb. Cell Factories 11, 83. https://doi.org/10.1186/1475-2859-11-83

Chisti, Y., Jauregui-Haza, U.J., 2002. Oxygen transfer and mixing in mechanically agitated airlift bioreactors. Biochem. Eng. J. 10, 143-153.

Garcia-Ochoa, F., Gomez, E., 2009. Bioreactor scale-up and oxygen transfer rate in microbial processes: An overview. Biotechnol. Adv. 27, 153-176.

Garcia-Ochoa, F., Gomez, E., Santos, V.E., Merchuk, J.C., 2010. Oxygen uptake rate in microbial processes: An overview. Biochem. Eng. J. 49, 289-307.

Gezork, K.M., Bujalski, W., Cooke, M., Nienow, A.W., 2000. The transition from homogeneous to heterogeneous flow in a gassed, stirred vessel. Chem. Eng. Res. Des. 78, 363-370. https://doi.org/10.1205/026387600527482

Heijnen, J.J., 2005. Approximative kinetic formats used in metabolic network modeling. Biotechnol. Bioeng. 91, 534-545. https://doi.org/10.1002/bit.20558

Ho, Y.K., Doshi, P., Yeoh, H.K., Ngoh, G.C., 2015. Interlinked population balance and cybernetic models for the simultaneous saccharification and fermentation of natural polymers. Biotechnol. Bioeng. 112, 2084-2105. https://doi.org/10.1002/bit.25616

Kerkhoven, E.J., Lahtvee, P.-J., Nielsen, J., 2015. Applications of computational modeling in metabolic engineering of yeast. FEMS Yeast Res. 15, 1-13. https://doi.org/10.1111/15671364.12199

Lueske, J., Kar, K., Piras, L., Pressler, J., 2015. Power Draw and Gas-Liquid Mass Transfer Characteristics of a Stirred-Tank Reactor with Draft Tube Configuration. Chem. Eng. Technol.

Moo-Young, M., Chisti, Y., Vlach, D., 1993. Fermentation of cellulosic materials to mycoprotein foods. Biotechnol. Adv. 11, 469-479.

Nauha, E.K., Visuri, O., Vermasvuori, R., Alopaeus, V., 2015. A new simple approach for the scale-up of aerated stirred tanks. Chem. Eng. Res. Des. 95, 150-161. https://doi.org/10.1016/j.cherd.2014.10.015

Oosterhuis, N.M.G., Kossen, N.W.F., 1984. Dissolved oxygen concentration profiles in a productionscale bioreactor. Biotechnol. Bioeng. 26, 546-550. https://doi.org/10.1002/bit.260260522

Paul, E.L., Atiemo-Obeng, V.A., Kresta, S.M., 2004. Handbook of Industrial mixing : science and practice. Wiley-Interscience, Hoboken, NJ :

Pollard, D.J., Ison, A.P., Shamlou, P.A., Lilly, M.D., 1997. Influence of a propeller on Saccharomyces cerevisiae fermentations in a pilot scale airlift bioreactor. Bioprocess Eng. 16, 273-281.

Ramkrishna, D., Song, H.-S., 2012. Dynamic models of metabolism: Review of the cybernetic approach. AIChE J. 58, 986-997. https://doi.org/10.1002/aic.13734 
Solà, A., Maaheimo, H., Ylönen, K., Ferrer, P., Szyperski, T., 2004. Amino acid biosynthesis and metabolic flux profiling of Pichia pastoris. Eur. J. Biochem. 271, 2462-2470. https://doi.org/10.1111/j.1432-1033.2004.04176.x

Sonnleitner, B., Käppeli, O., 1986. Growth of Saccharomyces cerevisiae is controlled by its limited respiratory capacity: Formulation and verification of a hypothesis. Biotechnol. Bioeng. 28, 927-937. https://doi.org/10.1002/bit.260280620

Tervasmäki, P., Latva-Kokko, M., Taskila, S., Tanskanen, J., 2016. Mass transfer, gas hold-up and cell cultivation studies in a bottom agitated draft tube reactor and multiple impeller Rushton turbine configuration. Chem. Eng. Sci. 155, 83-98. https://doi.org/10.1016/j.ces.2016.07.048

Vrábel, P., van der Lans, R.G.J.M., Luyben, K.C.A.M., Boon, L., Nienow, A.W., 2000. Mixing in largescale vessels stirred with multiple radial or radial and axial up-pumping impellers: modelling and measurements. Chem. Eng. Sci. 55, 5881-5896. https://doi.org/10.1016/S00092509(00)00175-5 